\title{
WHY MINERAL CARRIERS ARE NECESSARY FOR MICROALGAE
}

\author{
T. N. Shchemelinina1, E. M. Anchugova1, O. B. Kotova ${ }^{2}$, S. Sun ${ }^{3}$, D. A. Shushkov², A. V. Gogonin ${ }^{4}$, \\ N. V. Likhanova ${ }^{5}$, O. M. Zueva ${ }^{1}$, Yu. S. Korchagina ${ }^{6}$ \\ ${ }^{1}$ Institute of Biology, FRC Komi Science Center, UB RAS, Syktyvkar, Russia; tatyanakomi@mail.ru \\ 2 Institute of Geology, FRC Komi Science Center, UB RAS, Syktyvkar, Russia; kotova@geo.komisc.ru \\ ${ }^{3}$ Southwest University of Science and Technology, Mianyang, Sichuan, P.R. China; shiysun@163.com \\ ${ }^{4}$ Institute of Agrobiotechnology, FRC Komi Science Center, UB RAS, Syktyvkar, Russia \\ ${ }^{5}$ RCSECT «Quantorium», Syktyvkar, Russia \\ ${ }^{6}$ EcoAlliance, Syktyvkar, Russia
}

\begin{abstract}
Abiotic, biotic and anthropogenic factors inhibit normal life of microorganisms. We have presented that the mineral carrier provides integrity and increases the growth of microalgal cells under stress conditions. Microalgae Chlorella vulgaris, immobilized on an analcime-containing rocks (biogeosorbent), are resistant to increased salinity (34\%o) and organic pollutants (phenolic water with a concentration of $10 \mu \mathrm{g} / \mathrm{dm}^{3}$ ). The advantage of the synergetic complex of the biogeosorbent from its individual components is the reduction of the period of water purification from phenols. Biodestruction of $83 \%$ of phenols in model water occurs in 3 days.
\end{abstract}

Keywords: stress factors, phenolic water, seawater, mineral carrier, analcime-containing rocks, microalgae, biogeosorbent, sorption, biodestruction.

\section{ПОЧЕМУ МИНЕРАЛЬНЫЕ НОСИТЕЛИ НУЖНЫ МИКРОВОДОРОСЛЯМ}

\author{
Т. Н. Щемелинина ${ }^{1}$, Е. М. Анчугова 1 , О. Б. Котова 2 , Ш. Сан ${ }^{3}$, Д. А. Шушков², А. В. Гогонин ${ }^{4}$, \\ Н. В. Лиханова ${ }^{5}$, О. М. Зуева ${ }^{1}$, Ю. С. Корчагина 6 \\ ${ }^{1}$ Институт биологии ФИЦ Коми научного центра УРО РАН, Сыктывкар, Россия \\ 2 Институт геологии ФИЦ Коми научного центра УРО РАН, Сыктывкар, Россия \\ 3 Юго-Западный научно-технический университет, Мяньян, Сычуань, Китайская Народная Республика, \\ ${ }^{4}$ Институт агробиотехнологии ФИЦ Коми научного центра УРО РАН, Сыктывкар, Россия \\ 5 ГАУ ДО РК «РЦДО» ДТ «Кванториум», Сыктывкар, Россия \\ ${ }^{6}$ ООО «ЭкоАльянс», Сыктывкар, Россия
}

\begin{abstract}
Функционирование микроорганизмов в биоотчистке экосистем препятствуют абиотические, биотические и антропогенные факторы. Показано, что минеральный носитель обеспечивает сохранность и увеличивает рост клеток микроводорослей в стрессовых условиях. Микроводоросли Chlorella vulgaris, иммобилизованные на анальцимсодержащей породе (биогеосорбент), проявляют толерантность к повышенной солености (34 \%о) и органическим загрязнителям (фенольная вода с концентрацией 10 мкг/дм³). Преимуществом синергетического комплекса биогеосорбента перед отдельными его составляющими является снижение периода очистки воды от фенолов. Биодеструкция 83 \% фенолов в модельной воде происходит за 3 суток.
\end{abstract}

Ключевые слова: стресс-факторы, фенольная вода, морская вода, минеральный носитель, анальцимсодержащая порода, микроводоросли, биогеосорбент, сорбция, биодеструкция.

Abiotic, biotic and anthropogenic factors inhibit normal life of microorganisms. Considerable experimental material has been accumulated at present, indicating an increase in the stability of cells immobilized on a cell carrier as compared with suspended microorganisms. The stability is expressed in the longer active functioning of the cells, while there is an increase in $\mathrm{pH}$ and temperature optimums, greater resistance to negative environmental influences. The immobilized cells are inhibited by rather higher concentrations of a specific substrate than suspended ones [13, 15]. Immobilization conditions and carriers should ensure minimal cell damage and inhibit desorption. Most standard methods of immobilizing microorganisms are potentially suitable for microalgae, if their cells receive enough light [3]. Mineral carriers - natural zeolites and zeolitecontaining rocks - can become one of the more accessible and inexpensive carriers of microalgae. Our studies showed that zeolite-containing rocks not only stabilized microalgae, but also solved problems of bio-purification from organomineral pollutants [11, 12, 15]. Further it seems interesting to evaluate effect of stressful conditions on microalgae, which are immobilized on analcime-containing rocks.

\section{OBJECTS AND METHODS OF RESEARCH}

As the objects of study, we selected:

- a mineral carrier - analcime-containing rocks of the "Veslyana" occurrence (Koinskaya zeolite-bearing area, Komi Republic) with a grain size of $0.1-0.25 \mathrm{~mm}$;

- Chlorella vulgaris Beijerinck f. globosa Andreeva [8] microalgae (MA) culture from SYKO A collection of the Institute of Biology, FRC Komi Science Center, UB RAS;

Для цитирования: Щемелинина Т. Н., Анчугова Е. М., Котова О. Б., Сан Ш., Шушков Д. А., Гогонин А. В., Лиханова Н. В., Зуева О. М., Корчагина Ю. С. Почему минеральные носители нужны микроводорослям // Вестник геонаук. 2020. 2(302). С. 24-28. DOI: 10.19110/geov.2020.2.4.

For citation: Shchemelinina T. N., Anchugova E. M., Kotova O. B., Sun S., Shushkov D. A., Gogonin A. V., Likhanova N. V., Zueva O. M., Korchagina Yu. S. Why mineral carriers are necessary for microalgae. Vestnik of Geosciences. 2020. 2(302). Pp. 24-28. DOI: 10.19110/geov.2020.2.4. 
- model phenolic water with a concentration of $10 \mu \mathrm{g} / \mathrm{dm}^{3}$;

- seawater taken in the coastal zone of Vladivostok City, salinity $34 \%$ [1].

\section{Characterization of microalgae strain}

C. vulgaris f. globosa - Chlorophyta unicellular alga. Spherical cells are from 3.3 to 13.3 microns in diameter. The species is characterized by a wide area of distribution in the aquatic and terrestrial environments [2]. Chlorella is an alpha-mesosaprobiont species that can withstand a significant organic pollution.

\section{Characterization of the mineral carrier}

The analcime-containing rocks (sample 551) were selected from the "Veslyana" occurrence located on the left bank of the Veslyana River at a distance of about $500 \mathrm{~m}$ from the course. The occurrence was found by the employees of Komigeologiya LLC during a complex geological survey with a scale of 1: 2,000,000 (1987-90) and revision works on agromineral raw (2001) and was characterized by minimal overburden and favorable mining and geological conditions. The occurrence is located within the Koinskaya zeolite-bearing area (Knyazhpogost district of the Komi Republic), which is confined to crest of the Sindor swell on the western slope of the Timan Ridge [10].

The specimen of the analcime-containing rocks is represented by Permian brownish-gray argillite. According to $\mathrm{X}$-ray phase analysis the sample is predominated by quartz and analcime. Goethite, hematite and feldspar minerals are minor. Layered silicates are diagnosed by weak reflexes and probably represented by mixed-layer low-ordered illite/smectite. The silicate analysis revealed the following components (wt. \%): $\mathrm{SiO}_{2}-54.46, \mathrm{TiO}_{2}-0.92, \mathrm{Al}_{2} \mathrm{O}_{3}-$ 17.68, $\mathrm{Fe}_{2} \mathrm{O}_{3}-8.11, \mathrm{FeO}-0.31, \mathrm{MnO}-0.049, \mathrm{CaO}-$ $0.79, \mathrm{MgO}-1.59, \mathrm{~K}_{2} \mathrm{O}-2.16, \mathrm{Na}_{2} \mathrm{O}-4.34, \mathrm{P}_{2} \mathrm{O}_{5}-$ 0.13 , LOI $-8.92, \mathrm{CO}_{2}-0.13$ (Total 99.46).

The isotherms of nitrogen adsorption-desorption of analcime-containing rocks are of IV(a) type according to the IUPAC classification [16]. They are characterized by the presence of a hysteresis loop and typical of mesoporous sorbents. The adsorption curve shows a sharp rise at low pressures, indicating the presence of micropores in the sample $(<2 \mathrm{~nm})$. The rise in the adsorption curve at a relative pressure close to 1 indicates the presence of macropores. The hysteresis loop can be classified as $\mathrm{H} 3$ and $\mathrm{H} 4$ types, since clay minerals and zeolites are also present in the sample. The pore size distribution curve is characterized by a narrow bimodal distribution of pore radius in the range of $0.8-3 \mathrm{~nm}$ with maxima of 0.96 and $2.15 \mathrm{~nm}$. Structural characteristics are presented in Table 1.

The analcime-bearing rocks should be considered as sorption raw of mixed composition, since zeolites are asso- ciated with clay minerals, which are also characterized by high sorption properties.

Microalgae cells were counted using a GoryaevThoma counting chamber [14] with Biomed 3 microscope, binocular: LED, quadruple nosepiece, Achromat $4 \mathrm{x} / 10 \mathrm{x} / 40 \mathrm{x} / 100 \mathrm{xlenses}$. The dehydrogenase activity of the aqueous suspension was studied according to the methodology of the All-Russian Scientific Research Institute of Water Resources [9].

The surface morphology of samples with immobilized microalgae was studied by TESCAN VEGA 3 LMH scanning electron microscope with X-Max Oxford Instruments energy dispersion attachment at an accelerating voltage of $5 \mathrm{kV}$.

The chemical composition of the rocks was determined by silicate analysis with 12/14 components.

$\mathrm{X}$-ray phase analysis was performed by Shimadzu XRD 6000 diffractometer $\left(\mathrm{CuK}_{\alpha}\right.$ radiation, $\mathrm{Ni}$ filter, $30 \mathrm{kV}, 30 \mathrm{~mA})$. A powder sample was taken in the range $2-652 \theta$ with a speed of $1 \mathrm{deg} / \mathrm{min}$ and a scan step of $2 \theta$ $0.05^{\circ}$. The phase composition of the clay fraction was determined by X-ray diffraction of oriented and non-oriented samples subjected to standard diagnostic treatments.

The specific surface area, the volume of micro- and mesopores, and the total pore volume of the initial untreated sample were determined by the low-temperature physical sorption of nitrogen using NOVA 1200e Quantachrome analyzer of surface area and pore size at a temperature of $-196{ }^{\circ} \mathrm{C}$ with preliminary degassing at $350{ }^{\circ} \mathrm{C}$ in vacuum within 2 hours. The specific surface area was calculated by BET method, the mesopore volume - by BJH method, the micropore volume by Dubinin-Astakhov method.

The amount of phenols was analyzed by capillary gas chromatography [5].

The microalgae strain was grown on Tamiya medium in Biostat ${ }^{\circledR}$ A MO UniVessel ${ }^{\circledR}$ Glass BB-8822000 2L $230 \mathrm{~V}$ bioreactor for 3-5 days under conditions of liquidphase fermentation at $350 \mathrm{rpm}$, temperature $25-27^{\circ} \mathrm{C}$, pH $5.5-6.5$, lightening with a lamp $175-150 \mathrm{~V} 50 \mathrm{~Hz}$ until a titer of cells in a suspension of $10^{8}$ cells $/ \mathrm{cm}^{3}$ was reached. Tamiya medium (per $1 \mathrm{dm}^{3}$ of deionized water) of the following composition: $\mathrm{KNO}_{3}-5 \mathrm{~g}, \mathrm{KH}_{2} \mathrm{PO}_{4} \times 3 \mathrm{H}_{2} \mathrm{O}-$ $1.25 \mathrm{~g}, \mathrm{MgSO}_{4} \times 7 \mathrm{H}_{2} \mathrm{O}-2.5 \mathrm{~g}$, microelement solutions $1 \mathrm{~cm}^{3}$ each. The trace element solutions are as follows (per $1 \mathrm{dm}^{3}$ of deionized water).

1. Alkaline solution of EDTA: EDTA $-50 \mathrm{~g} ; \mathrm{KOH}-$ $31 \mathrm{~g}$.

2. Acidic iron solution: $\mathrm{FeSO}_{4} \times 7 \mathrm{H}_{2} \mathrm{O}-4.98 \mathrm{~g}$, $\mathrm{H}_{2} \mathrm{SO}_{4}-1 \mathrm{~cm}^{3}$.

3. Boric acid solution: $\mathrm{H}_{3} \mathrm{BO}_{3}-11.42 \mathrm{~g}$.

4. The solution of trace elements: $\mathrm{ZnSO}_{4} \times 7 \mathrm{H}_{2} \mathrm{O}-$ $8.82 \mathrm{~g} ; \mathrm{MnCl}_{2} \times 4 \mathrm{H}_{2} \mathrm{O}-1.44 \mathrm{~g} ; \mathrm{MoO}_{3}-0.71 \mathrm{~g} ; \mathrm{CuSO}_{4} \times$ $5 \mathrm{H}_{2} \mathrm{O}-1.57 \mathrm{~g} ; \mathrm{Co}\left(\mathrm{NO}_{3}\right)_{2} \times 6 \mathrm{H}_{2} \mathrm{O}-0.49 \mathrm{~g}$.

Then, MA suspension was sprayed onto a mineral carrier (analcime-containing rocks) and dried at a temperature of $25^{\circ} \mathrm{C}$. The ratio of the composition of the biogeo-

Table 1. Specific surface area and porosity of the analcime-containing rocks, size $\mathbf{0 . 1}-\mathbf{0 . 2 5} \mathrm{mm}$

Таблица 1. Удельная площадь поверхности и пористость анальцимсодержащей породы, крупность 0.1-0.25 мм

\begin{tabular}{c|c|c|c|c|c}
\hline $\begin{array}{c}\text { Specific surface area, } \mathrm{m}^{2} / \mathrm{g} \\
\text { Удельная площадь } \\
\text { поверхности, } \mathrm{M}^{2} / \Gamma\end{array}$ & $\begin{array}{c}\text { Constant } \\
\mathrm{C}_{\mathrm{BET}}\end{array}$ & $\begin{array}{c}\text { Total pore } \\
\text { volume } \mathrm{cm}^{3} / \mathrm{g} \\
\text { Общий объем } \\
\text { пор, } \mathrm{cm}^{3} / \Gamma\end{array}$ & $\begin{array}{c}\text { Mesopore } \\
\text { volume } \mathrm{cm}^{3} / \mathrm{g} \\
\text { Объем мезопор, } \\
\mathrm{cm}^{3} / \Gamma\end{array}$ & $\begin{array}{c}\text { Micropore } \\
\text { volume, } \mathrm{cm}^{3} / \mathrm{g} \\
\text { Объем } \\
\text { микропор, } \mathrm{cm}^{3} / \Gamma\end{array}$ & $\begin{array}{c}\text { Average pore } \\
\text { radius, } \mathrm{nm} \\
\text { Средний радиус } \\
\text { пор, нм }\end{array}$ \\
\hline 39.66 & 223.54 & 0.0484 & 0.0365 & 0.017 & 2.44
\end{tabular}


sorbent: mineral carrier is $85-90 \%$, microalgae strain C. vulgaris $-10-15 \%$.

\section{RESULTS AND DISCUSSION}

Chlorella vulgaris microalgae immobilized on the analcime-containing rocks. An electron microscope study of the biogeosorbent showed the presence of MA cells on the surface of the sample (Fig. 1). During the adsorption immobilization of the cells, which are caused by electrostatic forces, several types of adhesive interaction are simultaneously realized, so, it is difficult to determine the role of each of them individually. According to [4], covalent and ionic interactions have the greatest effect on the binding of $C$. vulgaris microalgae to the carrier.

Influence of stress factors. The biogeosorbent was tested for resistance to relatively high temperatures, to conditions of increased salinity and to the influence of organic pollutants. To do this, the biogeosorbent samples (Table 2) were thermostated at high temperatures, added into model phenolic wa- ter and seawater taken in the coastal zone of Vladivostok. The control sample was not exposed to stress factors.

Samples No. 1, 2, $0.1 \mathrm{~g}$ each, were added into the sterile Tamiya nutrient medium and the control cultivation was carried out, periodically selecting samples to count MA cells and determine dehydrogenase activity (Table 3 ). For samples of biogeosorbent No. 3 and $4,50 \mathrm{~cm}^{3}$ of sea or phenolic water was poured into flasks $100 \mathrm{~cm}^{3}$ and $0.1 \mathrm{~g}$ of biogeosorbent was added. Experimental conditions: room temperature, lighting with a grow lamp, aeration at $180 \mathrm{rpm}$.

Being the most informative parameters for assessing cell viability, metabolic and synthetic activity [13], the biomass yield and dehydrogenase activity were estimated during the experiment (on days 3, 7, 14 and 30).

The biomass yield (the ratio of newly synthesized substance of growing cells to the amount of substrate consumed - the source of matter and energy for cell growth) is a characteristic of the efficiency of the conversion of the substrate to biomass. The conversion process is derived from metabolism (plurality of biochemical reactions in
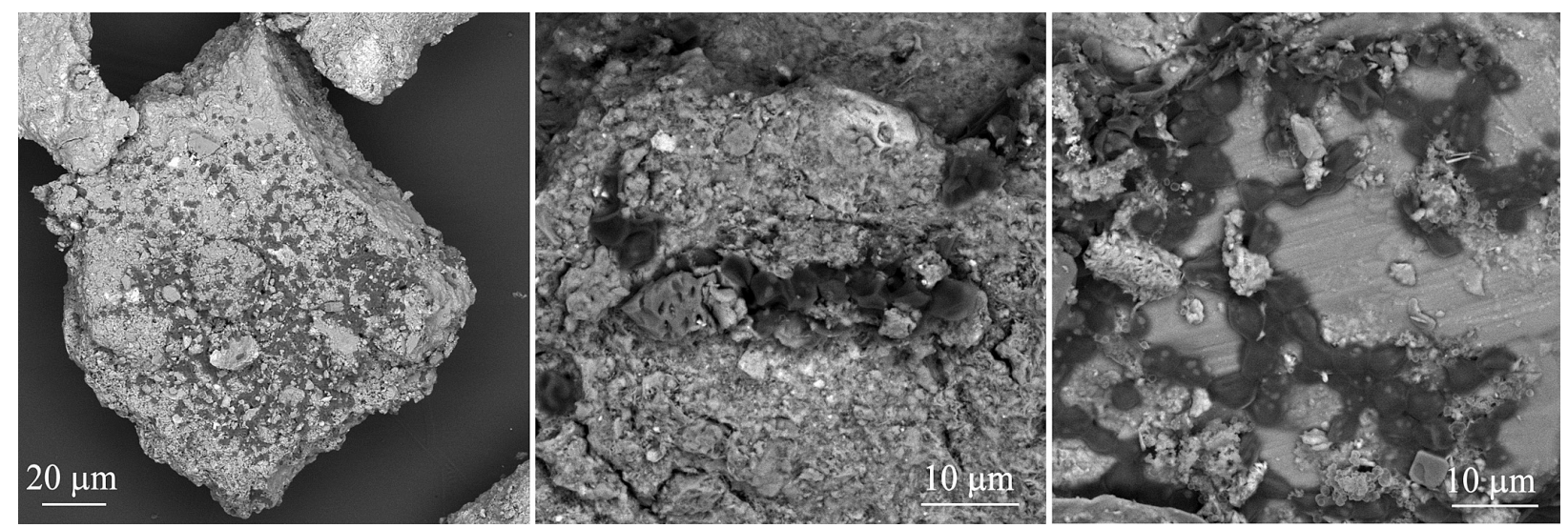

Fig. 1. SEM images of Chlorella vulgaris microalgae immobilized on the analcime-containing rocks

Рис. 1. СЭМ-изображения микроводорослей Chlorella vulgaris, иммобилизованных на анальцимсодержащей породе

Table 2. Experimental conditions

Таблица 2. Условия эксперимента

\begin{tabular}{|c|c|c|}
\hline $\begin{array}{c}\text { Biogeosorbent sample No. } \\
\text { Номер образца } \\
\text { биогеосорбента } \\
\end{array}$ & $\begin{array}{l}\text { Conditions of sample processing } \\
\text { Условия обработки образцов }\end{array}$ & $\begin{array}{c}\text { Exposure time, days } \\
\text { Время экспозиции, сутки }\end{array}$ \\
\hline 1 & Control / Контроль & - \\
\hline 2 & Temperature $80^{\circ} \mathrm{C} /$ Температура $80^{\circ} \mathrm{C}$ & 1 \\
\hline 3 & $\begin{array}{c}\text { Seawater, salinity } 34 \% o \\
\text { Морская вода, соленость } 34 \%\end{array}$ & 30 \\
\hline 4 & $\begin{array}{c}\text { Model phenolic water } 10 \mu \mathrm{g} / \mathrm{dm}^{3} \\
\text { Модельная фенольная вода с концентрацией } 10 \text { мкг/дм }{ }^{3}\end{array}$ & 30 \\
\hline
\end{tabular}

Table 3. Titer of cells of Chlorella vulgaris microalgae, cells $/ \mathrm{cm}^{3}$

Таблица 3. Титр клеток микроводорослей Chlorella vulgaris, кл/см${ }^{3}$

\begin{tabular}{c|c|c|c|c}
\hline $\begin{array}{c}\text { Время экспозиции, сутки } \\
\text { Exposition time, day }\end{array}$ & \multicolumn{4}{|c}{ Biogeosorbent sample No. / № образца биогеосорбента } \\
\cline { 2 - 5 } & $2.4 \times 10^{5}$ & 2 & 3 & $\begin{array}{c}\text { single cells detected } \\
\text { обнаружены единичные клетки }\end{array}$ \\
\hline 3 & $1.9 \times 10^{6}$ & - & $\begin{array}{c}\text { то же } \\
\text { id. }\end{array}$ & $2.2 \times 10^{6}$ \\
\hline 7 & $1.4 \times 10^{7}$ & - & » & $3.7 \times 10^{6}$ \\
\hline 14 & $1.3 \times 10^{7}$ & - & $1.8 \times 10^{4}$ & $1.1 \times 10^{7}$
\end{tabular}

Note: Designations 1-4 are taken from Table 2. / Примечание: Обозначения 1-4 - из табл. 2. 
cells) [6]. The preferable medium for MA cultivation and their maximum yield is Tamiya medium, since it is a nutrient solution of a high concentration of mineral salts. This medium was used to cultivate a control sample of biogeosorbent and to test the survival of samples No. 2 and 3.

In the Tamiya nutrient medium, a gradual accumulation of the biomass of $C$. vulgaris occurred in the control sample. The maximum yield was distinguished on day 14 (Table 3). Dehydrogenase activity directly correlated with an increase in the number of cells (Fig. 3).

Temperature. No living cells were found in the sample of the nutrient medium in which the biogeosorbent thermostated at a temperature of $80{ }^{\circ} \mathrm{C}$ was placed. No dehydrogenase activity was detected (Table 3, Fig. 2).

Salinity of water. The most important abiotic factor in the habitat of aquatic organisms, including unicellular algae, is the total salinity of seawater. In the first 14 days of culturing a sample of biogeosorbent No. 4 in seawater with a salinity of $34 \%$, single MA cells were detected, then the biomass increased by day 30 (Table 3). Dehydrogenation processes corresponded to the dynamics of the accumulation of MA cells (Fig. 2).

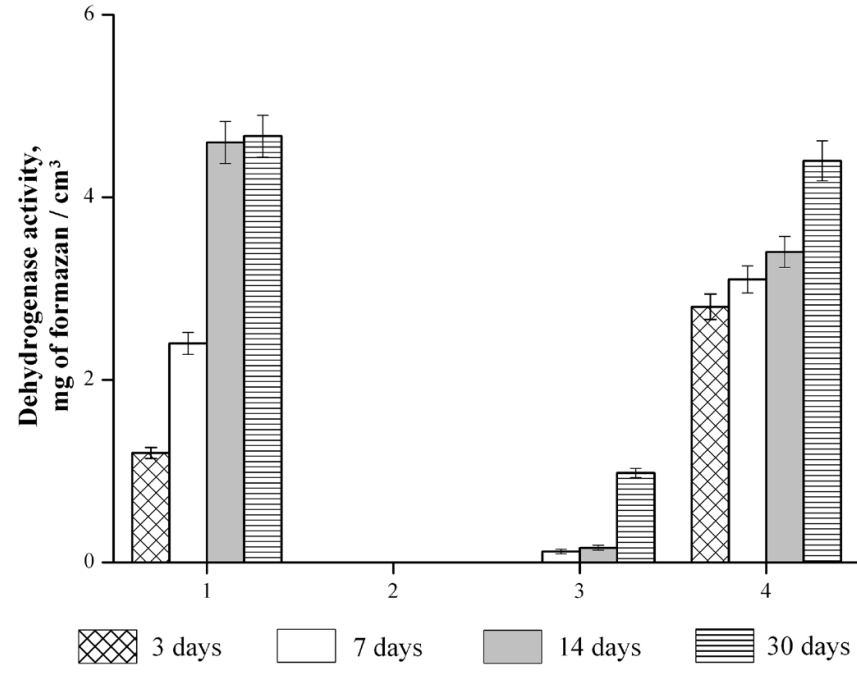

Fig. 2. Dehydrogenase activity of biomass. Designations $1-4-$ from Table 2

Pис. 2. Дегидрогеназная активность биомассы. Обозначения $1-4-$ из табл. 2

Organic pollutant. Phenol is especially dangerous because it is easily soluble in water. To accelerate biooxidation of organic pollutants the biochemical, biological adsorption and other methods are used [7].

We noted a high tolerance of MA to phenolic water with a mass concentration of $10 \mu \mathrm{g} / \mathrm{dm}^{3}$. When the biogeosorbent was introduced into phenolic water, MA desorption occurred, followed by cell cultivation in the medium. By the end of 30 days, the cell titer in this variant was similar to the titer of the cells of the control sample (Table 3). Dehydrogenase activity was increasing during biomass accumulation (Fig. 2).

Phenol destruction. The dynamics of the phenol content after the biogeosorbent (AMA) had been applied was studied. For comparison, a mineral carrier - analcimecontaining rocks without microalgae (A), suspended microalgae (MA) - was tested. Model phenolic water with- out additives was taken as a control: zero control (K0) analyzed for phenol content at the beginning of the experiment, and experimental control (EC) - analyzed for phenol content after 3 and 45 days.

After 3 days from the start of the experiment, adsorption and biooxidation processes were noted in all variants (Fig. 3). The maximum treatment of phenols regarding zero control was distinguished with exposure time. In suspended MA treatments, phenols were dropped by $74 \%$ in 3 days and $90 \%$ in 45 days. Analcime-containing rocks showed high sorption activity to phenols -78 and $97 \%$ of the zero control for 3 and 45 days, respectively.

A synergetic complex of microorganisms $C$. vulgaris and analcime-containing rocks contributed to the intensifying of sorption and destruction of phenolic compounds compared to similar processes that occur when only analcite-containing rock or a MA suspension are introduced into the water (Fig. 3). Algorithm of the biogeosorbent functioning: sorption of phenols by a biogeosorbent $\rightarrow$ active absorption by microalgae $\rightarrow$ accumulation $\rightarrow$ biodeostruction. Moreover, when phenolic water is treated with the biogeosorbent, partial desorption of $C$. vulgaris microalgal cells from the carrier occurred, and the phenol biodegradation processes were carried out simultaneously by immobilized and suspended cells. In the joint process of biological and sorption treatment of the model water by the biogeosorbent, the efficiency of phenols reduction was 84 and $98 \%$ of the zero control for 3 and 45 days, respectively.

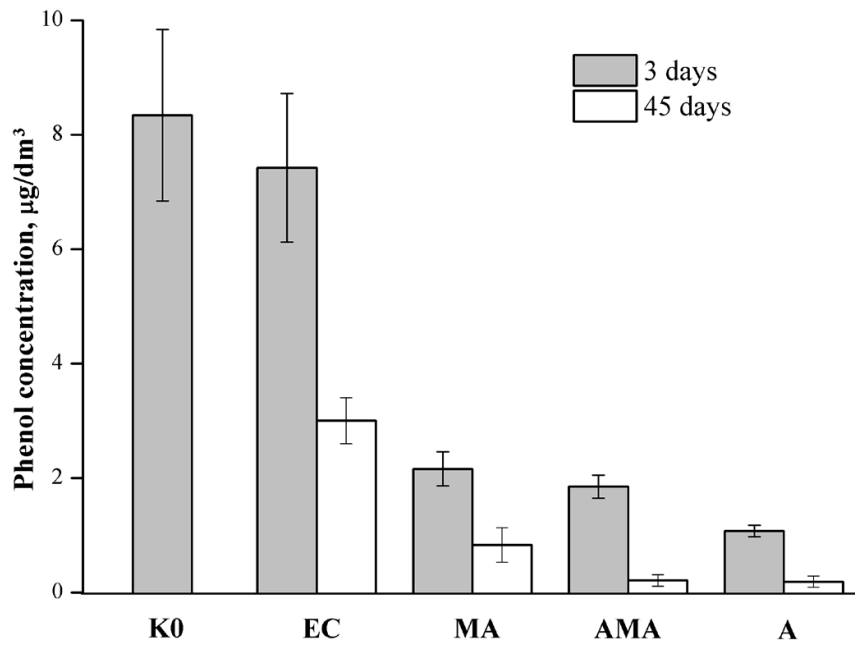

Fig. 3. Efficiency of phenol reduction in water relative to the zero control (K0) and experimental control (EC), mg/dm ${ }^{3}$ : MA suspended microalgae, A - analcime-containing rocks, AMA analcime-containing rock with immobilized microalgae

Рис. 3. Эффективность очистки воды от фенолов относительно нулевого контроля (К0) и контроля экспериментального (КЭ), мг/дм ${ }^{3}$ : МВ - микроводросли, А - анальцимсодержащая порода, АМВ - анальцимсодержащая порода с иммобилизированными микроводорослями

In the control variant phenol content decreased due to physical weathering, so it is more advantageously to compare it with EC. Reducing the amount of phenols for 3 and 45 days was: MA variant -70 and $72 \%, \mathrm{~A}-25$ and $93 \%$, AMA -82 and $93 \%$, respectively (Fig. 3).

Thus, the analcime-containing rocks are a "transport base" for $C$. vulgaris microalgal cells, preserving them un- 
der stressful conditions. Introducing it into a nutritious environment, microalgal cells re-activate their vital activities. C. vulgaris microalgae are tolerant to increased salinity $(34 \%$ ) and saturation with organic pollutants (phenolic water with a concentration of $\left.10 \mu \mathrm{g} / \mathrm{dm}^{3}\right)$.

Any agent used (C. vulgaris microalgae, analcimecontaining rocks, the biogeosorbent) is effective in remediation of phenols, but a distinctive feature of the biogeosorbent and its advantage is the reduction in the cleaning period, when used, and absence of secondary wastes due to biodegradation of phenols in the sorbent.

\section{Conclusions}

Thus, the algorithm of biogeosorbent functioning is as follows: sorption of phenols by the biogeosorbent $\rightarrow$ active absorption by microalgae $\rightarrow$ accumulation $\rightarrow$ biodeostruction.

By comparing of the mineral composition and sorption-structural characteristics of analcime-containing rocks and sorbents with microalgae immobilized, phenol destructive properties of biogeosorbents were estimated. Chlorella vulgaris microalgae, immobilized on analcime-containing rocks was found to be tolerant to high salinity (34\%o) and organic pollutants (phenolic water with a concentration of $10 \mu \mathrm{g} / \mathrm{dm}^{3}$ ). The mineral carrier provides preserving the cell viability and increases the growth of microalgae cells.

The advantage of the synergetic complex of the biogeosorbent over its individual components is the reduction of the period of phenol treatment in water. Biodegradation of $83 \%$ of phenols in model water occurs in 3 days.

The authors are grateful to the Geonauka CCU and the eco-analytical laboratory of the Institute of Biology, Komi SC $U B R A S$ for their assistance in the analytical work.

The reported study was funded by RFBR and NSFC according to the research project RFBR № 20-55-53019 and NSFC № 4191101331, 41672039.

This work was partially supported by State Task No. AAAA-A17-117121270025-1 "Development of biocatalytic systems based on enzymes, microorganisms and plant cells, their immobilized forms and associations for processing plant materials, obtaining biologically active substances, biofuels, remediation of contaminated soils and of wastewater treatment".

\section{References}

1. Aizdaycher N.A., Stonik I.V. Vliyanie solenosti morskoi vody na vidy roda Attheya West (Bacillariophyta) iz yaponskogo morya (Rossiya) (The influence of sea water salinity on species of the genus Attheya West (Bacillariophyta) from the Sea of Japan (Russia)). Algology, 2013, V. 23, No. 1, pp. 37-43

2. Andreeva V. M. Rod Chlorella: morfologiya, sistematika, printsipy klassifikatsii (Genus Chlorella: morphology, systematics, principles of classification). Science, 1975, $110 \mathrm{p}$.

3. Vasilieva S. G., Lobakova E. S., Lukyanov A. A., Solovchenko A. E. Primenenie immobilizovannyh mikrovodoroslei v biotehnologii (Application of immobilized microalgae in biotechnology). Tomsk State University Journal, Ser. 16, Biology, 2016, No. 3, pp. 65-72.

4. Immobilizatsiya kletok na nositele ili na poverhnosti nositelya (Immobilization of cells on a carrier or on a carrier surface). URL: https://www.kazedu.kz/referat/174283/1
5. Metodika izmerenii massovoi kontsentratsii fenola metodom kapillyarnoi gazovoi hromatografii (Methodology for measuring the mass concentration of phenol by capillary gas chromatography). No. 88-17641-006-2013 (FR.1.31.2013.15054), 2013 Edition.

6. Minkevich I. G. Otsenka maksimalnyh znachenii vyhoda biomassy, osnovannaya na material'no-energeticheskom balance metabolizma kletok (Estimation of maximum biomass yield values based on the material and energy balance of cell metabolism) Computer Research and Modeling, 2019, V. 11, No. 4, pp. 723750. DOI: 10.20537/2076-7633-2019-11-4-723-750.

7. Ochistka stochnyh vod I udalenie fenolov (Wastewater treatment and phenol removal). URL: https://www.kaufmanntec. $\mathrm{ru} /$ publics $/ 20 /$

8. Patent 2703499 RF. Shtamm mikrovodoroslei Chlorella vulgaris Beijer. f. globosa V. Andr. Dlya ochistki prirodnyh vodoemov $i$ stochnyh vod promyshlennyh predpriyatii (Microalgae strain Chlorella vulgaris Beijer. f. globosa V. Andr. For the purification of natural reservoirs and wastewater of industrial enterprises). T. N. Schemelinina, E. M. Anchugova, A. V. Gogonin, D. V. Tarabukin, D. M. Shapenkov. Published: 10/17/2019, Bull. Number 29.

9. Rogovskaya P. I., Orgianskaya F. E. Rekomendatsii po metodam proizvodstva analizov na sooruzheniyah biohimicheskoi ochistki promyshlennyh stochnyh vod (Recommendations on methods for the production of analyzes at the facilities for biochemical treatment of industrial wastewater). Moscow: Stroyizdat, 1970, 104 p.

10. Shushkov D. A., Kotova O. B., Kapitanov V. M., Ignatiev A. N. Analtsimsoderzhaschie porody Timana kak perspektivnyi vid poleznyh iskopaemyh (Analcime-bearing rocks of Timan as a promising type of minerals). Syktyvkar, 2006, 40 p. (Scientific recommendations - to the national economy. Komi SC UB RAS, 123).

11. Schemelinina T. N., Kotova O. B., Anchugova E. M., Shushkov D. A., Ignatiev G. V. Tseolitovoe i glinistoe syre: eksperimentalnoe modelirovanie biogeosorbentov (Zeolite and clay raw materials: experimental modeling of biogeosorbents). Vestnik of the Institute of Geology, Komi SC UB RAS, 2018, No 9, pp. 50-57.

12. Schemelinina T. N., Kotova O. B., Kharzha M., Anchugova E. M., Pelovsky I., Kretesku I. Novye trendy v mehanizmah povysheniya proizvoditel'nosti materialov na mineral'noi osnove (New trends in the mechanisms for increasing the productivity of materials based on minerals). Vestnik of the Institute of Geology, Komi SC UB RAS, 2017, No. 6, pp. 40-42.

13. Yurin V. M., Ditchenko T. I. Immobilizovannye kletki $i$ fermenty. Uchebno-metodicheskii kompleks (Immobilized cells and enzymes. Training and metodology complex). Belarusian State University, 2014, 138 p.

14. Benjumovich M. S. The application of Poisson units to the determination of median lethal cell culture dose. Toxicology in vitro, 2001, V. 15, No. 6, pp. 671-675.

15. Shchemelinina T. N., Gömze L. A., Kotova O. B., Ibrahim J. E. F. M., Shushkov D. A., Harja M., Ignatiev G. V., Anchugova E. M. Clay- and zeolite-based biogeosorbents: modelling and properties. ÉpHtőanyag - Journal of Silicate Based and Composite Materials, 2019, V. 71, No. 4, pp. 131-137. https:// doi.org/10.14382/epitoanyag-jsbcm.2019.23

16. Thommes M., Kaneko K., Neimark A. V., Olivier J. P., Rodriguez-Reinoso F., Rouquerol J., Sing K. S. W. Physisorption of gases, with special reference to the evaluation of surface area and pore size distribution (IUPAC Technical Report). Pure and Applied Chemistry, 2015, V. 87, Is. 9-10, pp. 1051-1069.

Поступила в редакцию / Received 31.01.2020 